\title{
Tephras in deep-sea core PS2644: Time markers for the last glacial
}

Antje Voelker (UGM-LNEG, Portugal) and Haflidi Haflidason (Univ. Bergen, Norway)

Deep-sea core PS2644-5 from the northwestern margin of Iceland $\left(67^{\circ} 52.02^{\prime} \mathrm{N}, 21^{\circ} 45.92^{\prime} \mathrm{W} ; 777\right.$ $\mathrm{m}$ water depth) exhibits high sedimentation rates during the last glacial cycle that allow the clear distinction of Greenland stadial (GS)/ interstadial (GI) cycles in the proxy records (e.g., Voelker et al., 1998). Abundance records of rhyolitic, basaltic and tachylytic tephra grains, counted in the faction $>150 \mu \mathrm{m}$, indicate several tephra layers within the glacial sequence. Prominent tephras found in the core are a Katla ash within GI 21, North Atlantic Ash Zone II, which contains various eruptions, and a basaltic tephra at the Heinrich event 5/ GI 12 transition. Several minor abundance peaks were found around and within GI 8 and during Marine Isotope Stage 2. Tephra grains from prominent and minor peaks have been analyzed for their geochemical composition. Chemical classification of the tephras will allow to identify tephras known from the Greenland ice cores and other sediment cores from the North Atlantic and Nordic Seas and thus to correlate the various climate archives and their proxy records.

Poster at XVIII INQUA-Congress: Quaternary sciences - the view from the mountains. 21-27 July 2011 in Bern, Switzerland 